\title{
Existence and essence in Venda oral literature
}

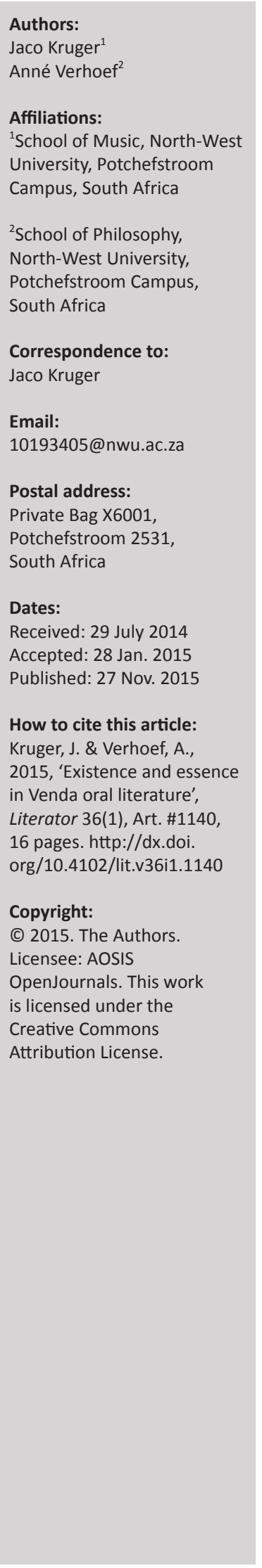

This article analyses two Venda ngano narratives that portray coming-of-age experiences. Viewed in juxtaposition, they express the radical shift from premodern modes of material and symbolic production to the reified consciousness of capitalist relations. This shift implicates the rootedness of local world views and global market forces within colonial and Western history, as well as contemporary political and economic conditions. The first narrative accordingly describes a classic rite of passage towards adulthood and citizenship within an ancient, precolonial world. Its protagonist is the culture hero whose society prioritises qualities and ideals like spirituality and social integration. In contrast, the second story is located in the colonial world. Its young hero migrates from his rural village to the city, and his adventure is an embryonic representation of the sociopolitical and racial dynamics of the colonial encounter. His actions evolve within a modernist world view, specifically a rational materialism driven by a teleology of progress that conceives economic organisation as the mediator of social relationships and personal fulfilment. The engagement of these diverse world views with history is explored from a perspective that aligns the ancient Venda concept of zwivhuya with Fromm's notion of qualitative freedom, of actualisation in all realms of human experience and of transcendence in all forms. The resplendent materiality presented in the second narrative is accordingly argued to conceal a spectre of fear and incomplete selfawareness. This poses a dilemma that speaks to all humanity, namely the need to transform the actual poverty of reified materiality into the wealth of an integrated world.

Bestaan en wese in Venda mondelinge literatuur. Hierdie artikel ontleed twee Venda ngano narratiewe wat volwassewording uitbeeld. Saamgelees openbaar hierdie verhale die radikale verskuiwing van premoderne vorms van materiële en simboliese produksie tot die gereifiseerde bewussyn van kapitalistiese verhoudings. Hierdie verskuiwing toon aan hoe gewortel plaaslike wêreldsbeskouings en globale markkragte is binne die koloniale en Westerse geskiedenis, asook kontemporêre politieke en ekonomiese omstandighede. Die eerste narratief beskryf derhalwe ' $n$ klassieke deurgangsrite na volwassenheid en burgerskap in 'n antieke, voorkoloniale wêreld. Die protagonis is 'n kultuurheld wie se samelewing voorrang gee aan kwaliteite en ideale soos spiritualiteit en sosiale integrasie. In teenstelling hiermee ontvou die tweede narratief in die koloniale wêreld. Die jong held verhuis van die platteland na die stad, en sy avontuur is 'n embrioniese uitbeelding van die sosiopolitieke en rassedinamiek van die koloniale ontmoeting. Sy optrede word bepaal deur 'n modernistiese uitkyk, spesifiek 'n rasionele materialisme wat gedryf word deur ' $n$ teleologie van vooruitgang waarvolgens ekonomiese organisasie die mediator van sosiale verhoudinge en persoonlike vervulling is. Die skakeling van hierdie uiteenlopende wêreldsbeskouings met die geskiedenis word verken vanuit ' $n$ perspektief wat die antieke Venda konsep van zwivhuya belyn met Fromm se begrip van kwalitatiewe vryheid, van aktualisering in alle domeine van menslike ervaring en van transendensie in alle vorme. Derhalwe word daar aangevoer dat die glinsterende materialiteit in die tweede narratief in der waarheid 'n skrikbeeld van vrees en gebrekkige selfgewaarwording verdoesel. En so kom die ganse mensdom te staan voor ' $n$ gedeelde dilemma, naamlik die noodsaaklikheid om die werklike armoede van 'n gereifiseerde materialiteit te transformeer tot die rykdom van 'n geïntegreerde wêreld.

\section{Introduction: The hero with a thousand faces lives on}

This discussion revolves around two stories narrated at the same event in 2011 in the village of Folovhodwe, situated in the Musina district. The stories belong to the $n g a n o^{1}$ genre, an

1.The $n g a n o$ (sing lungano: $\mathrm{pl}$ dzingano) category distinguishes itself from other Venda narrative genres by its obligatory responsorial form, shared between the narrator and her co-performers (the 'audience'). The latter periodically interjects the spoken response salungano! (lit. like a ngano story) into the narration, whilst also performing the chorus part in chants and songs that are integral to most ngano.

Expert ngano performance practice usually involves dramatic use of the voice, as well as limited gestures. In addition, actions by chorus performers also may generate performative meanings. 


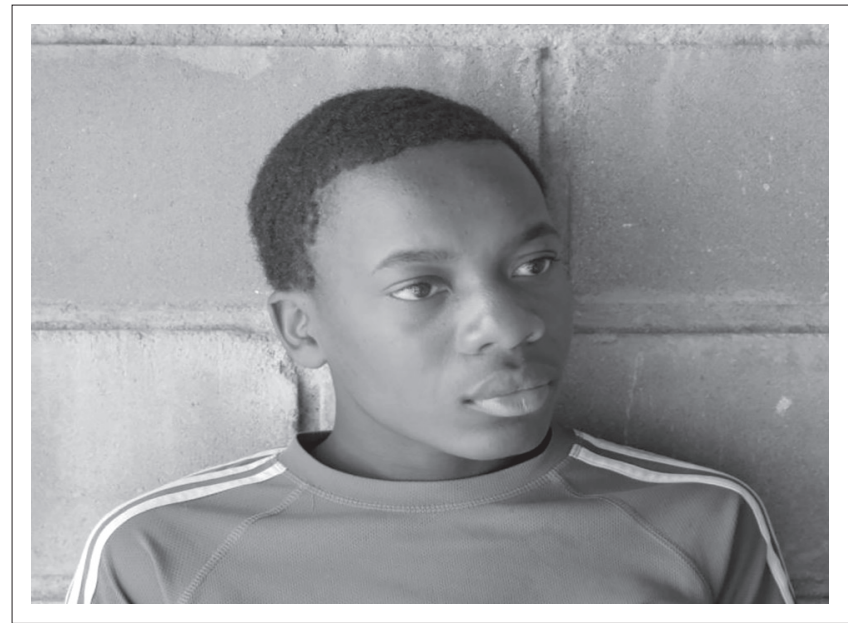

Source: This image was provided by the authors of this article Jaco Kruger and Anné Verhoef FIGURE 1: Zachary Tshamano.

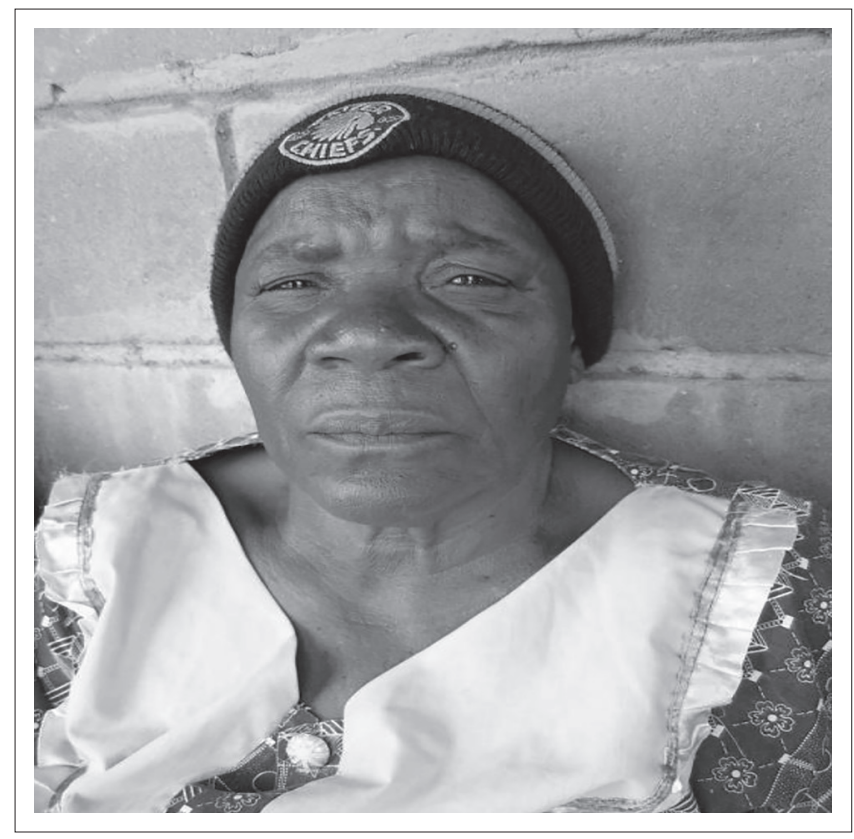

Source: This image was provided by the authors of this article Jaco Kruger and Anné Verhoef FIGURE 2: Matamela Makapile.

ancient form of Venda oral narrative. The narrator was 14-year-old Zachary Tshamano ${ }^{2}$ (Figure 1) who had heard the stories from his paternal grandmother during family gatherings around the cooking fire. According to Matamela Makapile (Figure 2), her grandchildren loved her stories so much that they forced her to tell them repeatedly. Makapile suffered a stroke early in 2011 and passed away some months later at her ancestral home in the neighbouring Nzhelele district. ${ }^{3}$

2.The performance took place on 17 June 2011 at Tshamano's home in the presence of Jaco Kruger, co-researcher Mathuvhelo Mavhetha and Tshamano's parents, Zachary Tshamano Snr. and Mashudu Mathala.

3.Makapile was born at Maranikwe in 1934 to parents who were small-scale farmers (Kruger 2013:176). She had a 'traditional' upbringing, and later married Kwareli (Kruger 2013:176). She had a "radith Rashaka, a migrant labourer, with whom she had two sons. A turbulent marriag led to divorce, after which she went to live at Folovhodwe with one of her sons, Zachary Tshamano Snr. She cared for Zachary Jr. his three brothers and sister whilst their parents worked in Johannesburg. Later during her life she became a superviso at a local orange farm. She had the reputation for having a fiery personality, served by her part-time occupation as a 'shebeen queen'.
Ngano performance no longer is the vital component of domestic life it once was. ${ }^{4}$ Tshamano ascribes the frequency of his grandmother's narrative performances not only to her love of storytelling, but also to communal living ${ }^{5}$ and the rituals at the cooking fire that are fading with the introduction of government housing schemes ${ }^{6}$ and electrification. And so it is not surprising that Tshamano had come to forget most of his grandmother's stories. However, two of them were imprinted in his memory to the degree of verbatim recall. The reason for this exceptional instance is his grandmother's explanation that these stories offered her grandchildren a model for their transformation into exemplary adults. ${ }^{7}$

Whilst the coming-of-age experience is commonly portrayed in ngano, these two stories, when viewed in juxtaposition, transcend its conventional, localised expression in a radical telescoping of certain core predicaments of the human condition. The protagonists of the two stories, called Dzwee and Olosi respectively, represent forms of that timeless, universal 'hero with a thousand faces' - of the narrative articulation of evolving consciousness, especially during periods of fundamental social transition marked intensively by conflicting ideals (Campbell 1973; Scheub 2012). Such conflict arises, from the familiar Marxist perspective, along the interface of humanity and nature, and, within humanity itself, that of existence and essence, objectification and selfaffirmation (Fromm 2005:148). These polarities signify a humanity existing precariously in the 'teeth of paradoxes' (Becker 1972:177), 'torn between a limited perception [of itself] and an exigency for the whole truth' (Garcia 1998:91). This truth manifests as the evolution of consciousness that makes it possible for 'men and women to come to full human maturity through the conditions of contemporary life' (Campbell 1973:388). From the Hegelian viewpoint this truth is not so much a final state as a continual quest for its everelusive realisation. We consequently do not seem to be any closer to resolving the contradiction of human embeddedness in an inhuman cosmos than ever before (Tarnas 1991:420). In fact, current history reveals our ongoing, often agonising engagement with the seemingly inexorable expansion of the modernist predicament. ${ }^{8}$

The juxtaposition of the stories of Dzwee and Olosi accordingly reveal a 'salvational historicity', a transitional moment that manifests an organic, precolonial social order 'in the process of penetration and subversion, reorganization

4.The former vitality of $n g a n o$ was related to the multiple ways in which they helped to organise older forms of social life (see Kruger \& Le Roux 2007; Kruger 2008; to organise olde
Kruger 2013)

5.Tshamano explained that daily life in the past involved people moving 'all over, working, running errands, doing chores and visiting. So, they gather[ed] in the evening to eat, discuss their day and tell stories because they [were] a family. (Kruger 2013:191.)

6.This well-known housing scheme, commonly referred to as 'the RDP' (from an earlier government Reconstruction and Development Plan) has taken the form of individual units, each with its demarcated plot, in contrast to former clusters of houses (Tshivenda: midi).

7.Bettelheim (2010:24) accordingly notes that oral narratives enable the young to conceptualise their existence whilst also presenting them with social ideals.

8.This is, for example, expressed in spellbinding ways in the motion pictures Disconnect (director Henry Rubin 2012) and Her (director Spike Jonze 2013) that explore the turbulent dynamics of human relations in cyberspace. 
and rationalization by nascent capitalism, yet still, for another long moment, coexisting with the latter' (Jameson 1981:148). Put differently, these stories embryonically express the gradual but radical shift in a local rural African population from premodern modes of material and symbolic production to capitalist relations with their attendant forms of reified consciousness. This shift implicates the rootedness of local world views and global market forces within colonial and Western history, as well as contemporary political and economic conditions.

The discussion that follows therefore firstly offers a short discussion of the challenge of narrative interpretation. This is followed by a translation of the narratives, as well as their analysis, which in turn informs an exposition of the precolonial cosmology of the first narrative, and of its reconceptualisation in the second narrative. The radical change this manifests is argued to encapsulate processes of materialist reification accompanying industrialising existence. Our argument culminates in reflection on the implications of this shift in consciousness, not only for Tshamano and his generation, but also for a wider humanity in its ongoing engagement with the challenges of modernity.

\section{The challenge of interpretation}

Our analysis of the stories is based on transcriptions from video recordings ${ }^{9}$ by Pfananani Masase (2011). ${ }^{10}$ With the exception of co-researcher Mathuvhelo Mavhetha's ${ }^{11}$ reaction of delight to the humorous second story, the performance did not offer any significant meanings beyond the narrative act itself. ${ }^{12}$ Tshamano's narration was unusually precise and clear, ${ }^{13}$ facilitating the translation of the stories by Masase and Kruger.

Our discussion pivots on the notion of ngano as an expression of consciousness that transcends its localised setting. As such, it is necessary to identify an appropriate interface between Tshamano's stories and certain aspects of narrative theory. Various competing yet complementing perspectives populate this interface. Most useful from the stock of older concepts are perhaps Jungian notions of the collective unconscious and transcendental imagination, which, in

\footnotetext{
9.Given that $n g a n o$ performance no longer is a vibrant cultural practice, virtually all current efforts towards its documentation take place in so-called induced natural
settings. In other words, performances take place on request, usually during the settings. In other words, performances take place on request, usually during the
daytime, and they may involve core participants only. However, family members daytime, and they may involve core participants only. However, family members The performances were recorded by means of an unobtrusive, small hand-held camera which did not impact in any significant way on conventional narrative camera which did not impact in any significant way on conventional narrative
practice. The video recordings of the performances are housed at the International Library of African Music, Rhodes University.

10.Rev. Masase is a doctoral student in divinity at the Potchefstroom campus of the North-West University.

11.Mavhetha is a retired civil servant, small-scale farmer and church minister. $\mathrm{He}$ and Kruger have been investigating ngano performance practice in the eastern Limpopo Valley since 2005.

12.There appear to be two main categories of ngano. Most $n g a n o$ contain chants and songs as an integral component of plots, as well as overall performance. A small number, including the two stories discussed here, contain only the salungano! verbal response (see footnote 1 ).

13.Given that most prominent ngano narrators are elderly, often frail women performances sometimes are characterised by poor diction and archaic language.
}

literature, take the familiar form of archetypes that embody primordial processes and figures, especially the human lifecycle and the recurring sets of actants that populate it. This position, with its structuralist ramifications, has proven vulnerable against charges of imprecision, reductionism and decontextualisation. Applied to narratology:

$[A]$ plausible account of meaning and purpose - why these putative archetypes should exist in the first place - is precisely what Jungian theory lacks, except in its vague emphasis on selfrealization as the ultimate goal of human thought and action. (Dutton 2009:129)

Ironically, Jungian theory simultaneously is acknowledged as prescient for the identification of 'some kind of inner psychological content, and with it a human nature, which lies under the endless diversity of cultural expression' (Dutton 2009:129). As such, narrative thematisation and patterning increasingly is conceptualised in terms of evolutionary imperatives: Homo sapiens now is also known as Homo symbolicus, a species uniquely hard-wired to explore the predicaments of its existence through storytelling (Deacon 1998; Dutton 2009:110). Narrative performance as such is posited as simulated, virtual experience that enables humanity to develop the 'potentially adaptive interpersonal and social capacities' (Dutton 2009:118, 132) required to navigate 'the endlessly complex mental worlds shared with others' (Deacon 1998:430). 'Its virtual nature notwithstanding, it is the symbolic realm of consciousness that we most identify with and from which our sense of agency and self-control originates.' (Deacon 1998:452.) It is therefore self-evident that narrative performance should feature recurrent themes related to shared human experience.

Tshamano's stories appropriately encapsulate all the narrative themes and categories identified in Booker's comprehensive tome (Booker 2004). ${ }^{14}$ They unfold in the form of an enthralling journey, one that has been undertaken by an infinite array of heroes from ancient myth to contemporary popular culture. Crucial to understanding the multivalence of this journey is the functioning of the human brain as a 'spontaneously active biological computer' whose unique prefrontal cortex recodes human experiences into representation with 'a deeper hidden logic' (Deacon 1998:436). Ngano narratives accordingly articulate powerful undercurrents of complex symbolism, the presence of which must be presupposed in any interpretation (Kruger \& Le Roux 2007; Kruger 2013). Modest as Tshamano's two stories may appear, they are construed tightly ${ }^{15}$ around certain profound images which portray an early phase of human life, namely that of a nascent consciousness of the world. In fact, emerging awareness as a condition of the entire life-cycle is a fundamental theme in ngano, and, as in human narrative practice at large, it is expressed on two semantic levels: Action unfolds selfevidently at the level of the plot in the form of a gripping

14.These are rebirth, voyage and return, the quest, rags to riches, overcoming the monster, comedy and tragedy.

15.The relative brevity, even abruptness, of many ngano is a stylistic trait linked with their multi-modal, dramatic enactment, as well as widely shared narrative images that do not require extensive verbal description (see footnote 1 ). 
journey of discovery. Often less apparent is an underlying, quite different voyage that manifests attempts to transcend conditions of naivety and egocentrism by means of a series of 'excruciatingly painful' experiences humanity initially may fail to understand, but which enable the eventual acquisition of insight required for a new, meaningful relationship with the self and the universe, as well as the frequent redemption of communities from some shared predicament (Bettelheim 2010:79; Booker 2004). ${ }^{16}$ As indicated, this process of revelation and consequence structures all ngano in various ways, and it features characters of all statuses. When related to the young person, it presents 'in imaginary and symbolic form the essential steps in growing up', the objective of which is social integration and the ability to conceptualise a rewarding existence (Bettelheim 2010:73). ${ }^{17}$

The untimely passing of Matamela Makapile is a regrettable impediment in the complete uncovering of this narrative undertow in the two stories discussed here, since Tshamano, himself in the process of coming-of-age, was able to offer a limited interpretation only of the primordiality of their roots and their expression in an ancient but now withering narrative practice (Tshamano 2013, 2014, pers. comm.). However, it has been possible to carry out a basic analysis in cooperation with co-researcher Mathuvhelo Mavhetha and certain elderly narrators. Most helpful were discussions with the elderly Nyamukamadi Ndou of Folovhodwe, as well as healer Miriam Vhengani from the nearby village of Tshiulungoma, whilst a story by Makapile provided a crucial key to interpretation (see Kruger 2013:177-180). We also triangulated our interpretations and findings by identifying the symbolic bedrock of ngano in other forms of oral expression as well as religious practices, not only locally, but also within the southern African indigenous cultural complex.

\section{The whiteness of being: Dzwee's story}

There was a certain young man called Dzwee. He was unhappy at home. It was a time of drought, and everybody was hungry. Dzwee quarrelled with his parents because he did not want to help them find food in the veld. ${ }^{18}$ He sulked and said, 'It is better that I leave home!'

He walked until he came to a large forest he did not know. Here he found a lion. He was scared and wanted to run away. But the lion said, 'Do not run away! Come and pull out this thorn from my paw. It has pierced me.'

The boy went up to the lion and pulled the thorn out. The lion said, 'Do not go around telling anyone that you removed the thorn and that you spoke to me.'

16.In Booker's terms, these travelling heroes must grapple with 'the monster', or the psychological and social limitations of self-actualisation. Once they have been 'reborn' in knowledge and experience - have discarded the rags of their youthfu naivety for riches, both real and symbolic - they frequently return 'home', a destination reached via the conventions of comedy and tragedy.

17.Whilst the psychoanalytical approach is subject to controversy, a circumspect application of Bettelheim's interpretations of folklore has proved useful in helping to uncover the symbolic foundations of ngano.

18.Veldfood is an important source of sustenance during droughts, and it remains a resource for the poor.
The boy went further and found a fish floundering on the bank of a river. The fish called, 'Hey, you, Dzwee! Come and throw me back into the water!' Dzwee became frightened and wanted to run away again. The fish said, 'Do not run away! Help me, and do not tell anyone that you spoke to me.' So Dzwee took the fish and threw it into the water.

Dzwee walked further and found a horse.

'Hey, Dzwee! What are you looking for here in the big forest?'

'I am just wandering around. I do not really know where I am going.'

'You will be devoured by predators because we are far from villages here.'

And so Dzwee mounted the horse. He rode him, he rode him! The horse arrived at a village and dropped the boy off.

Dzwee found a big shop that belonged to an Indian trader. He said, 'I am asking for work.'

The trader answered, 'My wife went to visit her family overseas. She took the key to the shop by mistake. Will you board a ship and fetch her?' They gave him food to take on his journey and he boarded the ship.

The country he travelled to was infested with lions. Those lions wanted to devour him! That lion who once had a thorn in its paw came there and said, 'Do not eat this one, he helped me.'

The boy found the woman. They boarded the ship. But when they were in the middle of the ocean, the woman dropped the key into the water.

When they arrived back home, the trader asked, 'Where is the key?' His wife explained, 'I dropped it into the water.' So the husband said to Dzwee, 'We are sending you back. Go and look for the key in the ocean.' They again gave the boy food for his journey. Dzwee boarded the ship. He spent two days at sea, looking into the water.

That fish he returned to the water saw him and asked, 'Hey, Dzwee, what are you looking for?' Dzwee answered, 'I am looking for a key.' The fish gathered all the other fish and they searched for the key. They found it and said, 'Here is the key, take it.'

Dzwee travelled back to the shop. When he arrived there, that trader said, 'Hey, we cannot repay this person for everything he did for us - no money can repay him.' They took him into the kitchen. They burned him, they burned him! But he did not die! He rose from the fire being whitewhite-white! Those Indians exclaimed, 'Hey, look!'

The owner of the shop said, 'I also want to be burned so that I no longer will be red.' He burned and died! All the Indians fled. The shop became the boy's.

The lion arrived there. He said, 'Hey, Dzwee, do you remember me rescuing you when the other lions wanted to devour you?' Dzwee answered, 'You do not live with people. Go to the veld!'

The fish spoke to him from the water, 'Hey, Dzwee, do you remember me helping you to find the key?' Dzwee said, 'You, stay in the water. You do not live with people.' 
The horse came closer. He asked, 'Hey, Dzwee, do you remember me bringing you here?' Dzwee replied, 'You, horse, you do not stay inside people's homesteads. Go and graze over there.'

This is the death of the story.

\section{A classic rite of passage}

Dzwee's journey to adulthood assumes the form of a classic rite of passage, with its stages of separation, transition and reintegration (see Van Gennep 1960). The first stage of this process involves separation from community, and it is usually triggered by some predicament. ${ }^{19}$ Drought commonly initiates action in ngano, showing how diverse personality types shape ensuing conflict. ${ }^{20}$ Young Dzwee aptly refuses to help his family find food, argues with his parents and, in a fit of petulant immaturity, leaves home. His is the typical dilemma of the young adult who is physically able to engage the world, but lacks the authority, emotional maturity and social experience to do so effectively. Growing up means he no longer can avoid residing in immaturity - he must depart on a quest for self-realisation.

Having left home, Dzwee now enters the transitional and most elaborate stage of his journey. At the level of the plot this involves his exploration of the physical world with its attendant dangers. ${ }^{21}$ Virtually all ngano are contained within a strictly bounded, precolonial world. This world offers anachronistic evidence of modern material culture, but this materiality has almost no bearing on the ancient cosmology of the genre, which offers an explicit, alternative model of social organisation and moral values to that of contemporary existence with its many ambiguities. Therefore, whilst social relations constitute the core of ngano, they almost always do so within the matrix of nature and its spiritualities which provide images for the conceptualisation of existence. There is a clear gradation in ngano from the ostensibly safe, controlled environment of human settlements to horticultural fields on their periphery which are the threshold to the untamed, often malignant veld that lies beyond. And so ngano links with wider narrative practice in which the ancient core image of the wilderness not only is the setting of dramatic action, but also expresses the turbulent, uncharted self 'in which inner darkness is confronted and worked through; where uncertainty is resolved about who one is; and where one begins to understand who one wants to be' (Bettelheim 2010:93). Dzwee fittingly arrives in a large, unfamiliar forest and wanders around aimlessly until he meets a lion, fish and horse.

19.Booker $(2004: 272-273)$ notes that the hero almost always is introduced into a community in which something is amiss: ' $[T]$ hings are in disarray, life is no longer flowing peacefully and happily.

20.For example, a husband finds a pigeon-pea tree (Cajanus cajan) in the veld during a period of drought, and feasts off its nuts. However, he informs no one else of his life-sustaining find. Later he also surreptitiously steals his baby's food. These moral crimes are detected, but he remains forever unrepentant. See Kruger (2013:207209).

21.In ngano, this also applies to unmarried girls who are constantly warned to avoid contact with strange men when they become old enough to fetch water and collect firewood.
The lion and fish are untamed inhabitants of the murky forest of the unconscious which must be restrained for purposes of self-actualisation (see Bettelheim 2010; Booker 2004). For ancient humanity, wild animals:

$[W]$ ere the primary manifestations of what was alien - the source at once of danger, and of sustenance - the great human problem was to become linked psychologically to the task of sharing the wilderness with these beings. (Campbell 1973:390)

As such, 'only when animal nature has been befriended, recognized as important, and brought into accord with ego and superego does it lend its power to the total personality' (Bettelheim 2010:78). The lion accordingly is symbolic of threat as well as male authority in Venda culture, and it features in both these capacities in ngano. ${ }^{22}$ Dzwee's encounter with the lion firstly presents an instance of the frequently paralysing existential fears that humanity must learn to mediate. And so Dzwee must conquer the lion in himself in order to fulfil his allocated patriarchal role with responsibility. The most common personified form of the lion in ngano is the husband who exudes aggression. In particular, he abuses his wife and children emotionally and physically. For Dzwee to become fully human, he therefore must learn to curb his potential for violence. In addition, the young hero's subsequent classic meeting with the $\operatorname{lion}^{23}$ offers him the time-honoured template for selflessness and the reciprocity that ultimately may be its reward.

Generally, Dzwee's ability to understand the lion (and subsequently, the fish) may be interpreted in relation to the mastering of speech as a social ideal. As we elaborate in our analysis of Olosi's adventure, ngano that portray coming-ofage experiences often describe how young people develop the power of speech and musical performance, and in this way display their intellectual competence and any other special capacity, especially spiritual power. Tshamano explained that the reason the lion and fish tell Dzwee not to reveal their conversations is that people could think he was 'crazy'. He was unable to clarify this remark, but exceptional ability, strange behaviour and inner turmoil typically characterise heroes in ngano. Bettelheim (2010:46) appositely remarks that 'if we do not understand what rocks and trees and animals have to tell us, the reason is that we are not sufficiently attuned to them.' In other words, the conversation between Dzwee and the lion may be that 'inner voice' - the innate, incipient capacity for reasoning and speech which here enables Dzwee's self-actualisation.

The fish performs a role similar to that of the lion. Whilst it obviously possesses much less physical strength, it also harbours harmful spirituality. ${ }^{24}$ And so Dzwee comes to

22.See Kruger \& Le Roux (2007:112-115) and Kruger (2013:96-99).

23.The correlation with Aesop's tale of Androcles and the lion is clearly evident here. Schwellnus (a Swiss Berlin missionary) includes this story in one of his Tshivenda primary school readers (1937:45-47), but it is not clear whether it has had any influence on the shaping of Dzwee's adventure.

24.Water is the setting of various spiritual forces, and action in ngano often takes place in or around rivers and pools. Fish rarely feature, whilst the crocodile, hippopotamus and python (the latter as a water-loving animal) frequently appear in a benign spiritual capacity. 
learn that physical frailty may belie spiritual power. ${ }^{25}$ The horse in turn plays two important structural roles in the story. Firstly, it appears as the contrasting terminal element in a three-part expansible image so typical of narrative technique (Scheub 1970). Dzwee's meetings with the lion and the fish constitute his initial phase of growth, one that equips him with increasing understanding of his irrational fears and aggressive potential. The horse lacks the violent, malignant qualities of the lion and fish: It has been domesticated and therefore may be mounted and ridden. Like the dog in ngano narratives, ${ }^{26}$ and alluded to in the final scene of the story, ${ }^{27}$ the horse may be conceptualised as the embodiment of "higher values" and a capacity for reasoning, that aspect of humanity 'closest to the surface of the mind, since it has as its function the relation to others and to the world around him', in particular showing humanity 'new ways of relating to savage and other beasts' (Bettelheim 2010:100).

The second structural role of the horse involves him carrying Dzwee to the next, climactic stage in the transitional phase of his journey. The horse's remark that 'we are far from villages here' not only points to the dangers of the forest, but also to the fact that Dzwee has not yet reached his final destination: His initial journey has served as self-introduction only, and there remain even more frightening, uncharted recesses of his personality to be discovered. And so he must depart for the nearest village which seems to offer redemption from the perils of the wild, but where he in fact will apply his recently acquired capabilities in resisting new danger, cast in the mould of conflicting humanity.

The role of Dzwee's deepest, potentially most destructive biological drives - his evil Mr Hyde - unusually is performed by an ethnically "non-African" out-group character. ${ }^{28}$ This is the first indication that the boundaries of the otherwise precolonial world of ngano have been permeated by a form of power that would bring about the kind of fundamental change that Olosi, the hero in the second story, must confront. In any case, the longstanding, constructive engagement in local life of South Africans of Indian descent is deliberately downplayed in Dzwee's adventure (Kruger 2013:196-197). Instead, the story activates irrational fears rooted in ignorance and cultural difference. Contrasts in appearance, dress, religion and economic power offer readily available images of conflict. The perception of the Indian person in local rural areas typically is that of the wealthy shopkeeper whose success is commonly ascribed to malevolent magical practices. In addition, there are widespread complaints by isolated local populations of economic exploitation related to their

25.As evidenced in the core image of the "evil" old woman (or witch) in ngano and other world narratives.

26.Dogs, as beloved domestic animals, feature commonly in ngano where they intercede in domestic conflicts. See Kruger (2004:108-109) and Kruger (2013:109111).

27.Whereas the lion and fish are banished to the wild, the horse is told to graze in the proximity of human settlement.

28. Evil characters in ngano generally are limited to adults engaged in family and communal conflict. Whilst the evil outsider in fact is quite familiar, he is almost exclusively Zimbabwean in origin, a practice possibly rooted in conflicting historical relations. dependence on what they experience as the limited, inferior merchandise Indian traders stock.

Having established the essential, symbolic foundation of Dzwee's adventure, it now becomes clear that the young hero is entering the final phase of his journey. He has travelled from the known confines of his home to the expansive, untamed veld and from there to an unfamiliar village which becomes the springboard for further exploration of his outer as well as interior world. Therefore, the key to the shop in fact is the means to unlocking Dzwee's inner resources that will complete his metamorphosis and enable his social reintegration. Furthermore - and in keeping with his obstructive role - the trader actually has a key to the shop. His role is to send Dzwee on a journey across the sea in order to challenge him further. Dzwee consequently must journey to a distant land, to his innermost being where he has to confront not one, but an entire pride of savage lions. As he discovers, however, the selfless person always is assured of assistance in the journey of life, and so the lion repays his initial deed of kindness by protecting him against the pride. ${ }^{29}$

Although the trader's wife and the key are located, this is not the end of Dzwee's ordeal. The key is dropped into the ocean, and the search continues. The sea as opaque, and not the natural domain of humanity, also makes it a logical setting for a quest. ${ }^{30}$ The landlocked setting of the Limpopo Valley may explain Tshamano's remark that, whilst the sea lacks the clearly identified perils of the forest, it too conjures up frightening images. The voyage across the sea is also structural in the sense that it activates the second encounter with the fish, which underscores the importance of altruism and interdependence. ${ }^{31}$

The conclusion of the transitional phase in Dzwee's rite of passage is his confrontation with the trader. Structurally, this scene constitutes the narrative apex or 'central crisis' that marks the binary form of typical rags-to-riches narratives (Booker 2004:64-65). Dzwee ostensibly is sent to the kitchen to have a meal after his return, but this hides the trader's actual intention to 'burn' him. The whiteness (vhutshena) of Dzwee's condition upon his emergence from the fire provides a crucial clue to the interpretation of the scene, and serves centrally in our concluding reflection on the broader implications of the two stories.

Burning as a means of transformation is one of the core metaphors and actual events in boys' circumcision schools in South Africa. The initiation lodge is destroyed by fire upon completion of the school to show that youth has been

29. Booker (2004:226) accordingly observes that the centrality of animal characters in coming-of-age narratives is linked to the assurance that the young hero, in the course of his life, 'will be guided step by step, and given help when it is needed.'

30.Booker (2004:270) describes the ocean in ancient Greek myth as a frightening setting for transformation and 'the ordering faculty of the human mind when it is cut off from life and the ability to see whole.' Tshamano's first visit to the sea took place during a school tour to Durban in July 2014. He explained that he waded into
the ocean, but was careful not to go in too deeply.

31.As in the case of the similarity between Dzwee and Androcles (see footnote 21), the image of speaking fish that provide humanity with some form of wealth, is common in world literature. 
left behind. In the Sepedi initiation song entitled 'Mo le mo' ['Here and here'], there accordingly is a line that notes: 'We are passing away like burning grass.' (Kruger 2013:195.)

Tshamano only had a vague notion of burning as metaphor of transformation and instead interpreted Dzwee's ordeal literally. To him the ferocity of the trader's actions is Dzwee's final challenge, and the young hero escapes the fire by virtue of magic (madambi).

Elderly ngano narrator Nyamukamadi Ndou of Folovhodwe interpreted Dzwee's whiteness as a condition of cleanliness or 'purity' (Ndou 2011, pers. comm.). ${ }^{32}$ This was confirmed by healer Miriam Vhengani from Tshiungani who added that images of people exiting water and fire symbolise spiritual capacity (Vhengani 2011, pers. comm.). Mathuvhelo Mavhetha similarly constantly emphasised the contrast between being dirty and clean - these are conditions of evil and virtue. This is illuminated by the redness that the trader fails to shake off. Whilst this is an implicit reference to the infamous red soil of the Soutpansberg, it essentially functions in contrast to whiteness. Redness not only signifies dirt, but also the failure of the trader to achieve a state of purity. Ultimately, therefore, the trader is Dzwee's immature, youthful self that has been left behind.

Whiteness thus generally is associated with spirituality, not only in Africa but also in other world cosmologies. ${ }^{33}$ Whilst further investigation is required, a tentative, interim reading suggests that Dzwee's whiteness may be metaphoric of allencompassing psychological integration and maturity. For Maslow (1954:147), this takes the form of self-actualisation, that eternal drive towards 'autonomy, independence, achievement, and for respect and praise over and above safety and parental love'. In ngano, the prerequisite for achieving this condition is maturity, or its onset, and certain life experiences, especially those related to anxiety. Booker (2004:212) notes in his typification of the voyage and return narrative category that 'only as death stares him in the face does [the hero] go through that change of heart which liberates him from his limited, egocentric state of awareness.' Transcending the self is a crucial prerequisite within Dzwee's world view, one that strives for collective unity around a higher ideal where the interior and exterior exist on a continuum, and where the striving for a better world is prioritised (Rossouw 2007:86). ${ }^{34}$ A ngano by Nyamukamadi Ndou (2011) accordingly describes the spiritual maturing of two girls, also cast in the mould of a journey. This maturing takes the form of 'coming out', or the identification of and

32.The description of Dzwee's transformation into whiteness ('A bua a mutshenatshena-tshena!') appears identically in a ngano by Ndou (see Kruger 2013 157-160).

No acceptable Tshivenda term for the concept of purity has yet been identified. Terms which go some way towards describing this condition include tamba (to wash) and penya (to shine), and they equate the notion of physical cleanliness to a desired spiritual and moral state.

33.This has been observed by Berglund (1976) for the Zulu, Junod (1927a, 1927b) for the Tsonga, and Turner (1967) for the Ndembu. In addition, whiteness frequently symbolises purity and spirituality in Christianity and other religions.

34.'Religie gaan oor die kollektiewe vereniging rondom ' $n$ hoër ideaal waar die innerlike en die uiterlike op ' $n$ kontinuum staan, en waar die strewe na ' $n$ beter wêreld voorop staan. unification with an ancestral spirit ('Hu do bva inwana'- 'The child will come out'). This means that they have gained access to the comforting presence of their spirit, which promotes a rewarding life (Ndou 2012, pers. comm.). Transcending the self and 'becoming one' with your spirit is an important prerequisite for incorporation into the precolonial cosmos.

And so Dzwee's story comes full circle with the final phase of his rite of passage. The young hero is ready to be reintegrated into society and to display his experience and knowledge. He has a final meeting with the animals during which he establishes his dominance over them: The lion, that ultimate symbol of ferocious wildness, is banished from humanity, as is the fish with its malignant spiritual power. The horse, symbolic of nature reined in, remains on the periphery of human existence, ready to serve at the behest of its owner. Dzwee now better understands the world's dangers and dilemmas. He has gained insight into social statuses and relationships, having discovered that cooperation and interdependence are basic social requirements. ${ }^{35}$ He has redeemed his youthful selfishness by helping the animals when they were in need. The hero 'has at last begun to move from his original centre of awareness, his limited little ego, to another, much deeper centre in himself, from which he can recognise his kinship with all life' (Booker 2004:102). It is in accordance with this newly attained status that Dzwee has become wealthy: He has discovered the key to a shop that stocks not merchandise, ${ }^{36}$ but the knowledge and confidence needed to act 'wisely, unselfishly and for the good of all' (Booker 2004:243). He is a culture hero in an ancient world that prioritises qualities and ideals like courage, perseverance, spirituality and social integration.

\section{The whiteness of existence: Olosi's story}

Here comes a story!

There was a man and his two wives. One of these women gave birth to a boy called Olosi. Olosi could do magic. He had a star on his forehead. When he lifted this star, he became an adult who had money like a white man.

His father's other wife saw that star and became jealous. She grabbed Olosi and threw him into a pool. But that child did not drown - he did not even become wet. ${ }^{37}$ So, she tried once more. When she went to fetch firewood far in the veld, she again threw him into the river.

People looked for him in all the villages in the district. A certain man said, 'I saw the child when I was collecting firewood near the river. He was in the water, but the river had not swept him away.' They went there and found Olosi. They returned home with him.

Olosi saw that he would be killed there. He lifted his star and became an adult.

35.This is also the message in Aesop's Androcles and the lion as well as a Shona narrative entitled 'The lion, the snake and the man' (see Granger 2007:76-80).

36. Hence the trader's remark that no money can repay Dzwee for his service.

37.Suggesting that drowning could be metaphoric of some unspecified harm, perhaps psychological violence. However, as our discussion indicates, it more likely seems to point to the power of Olosi as trickster hero, a feature supported by his magic star. 
'Mother, I think these people will kill me. I am leaving. I am going to find work.'

'Ah! You want to leave and look for work while still so young? ${ }^{\prime 38}$

'Yes, I am leaving to go and work my mother.'

Olosi's mother agreed and he left. He met a certain thin old $\operatorname{man}^{39}$ who was wearing a skin infested with lice. The man said, 'Hey, you! What makes you think you will find work with a nice suit like that? You will not find anything at all. People do not give work to a person who looks wealthy.'

That young man said, 'Really? Well then, give me your skin to wear.' So the thin old man gave Olosi the skin, while he put on the suit...

When the boy arrived at the next village, people said, 'Go away! We do not want a person covered in lice!' Olosi went to another village. Those people said, 'We really do not want a person crawling with lice! But we will take you to Mr. Baulo who is the chief.'

Mr. Baulo said, 'Come here, you. I will hire you.' He built the boy a small house far away from his own. He only went there to call Olosi for work.

That young man was so tired that he just slept on the first night. The second night he lifted his star and became a white man with money.

The following day Mr. Baulo said, 'Olosi, stay and look after my home. I am going to a social gathering. ${ }^{40}$ There is a white man I am going to see.' He left and Olosi remained behind. He lifted his star. A horse came there, kha-kha-kha$k h a$ ! The boy put on a white suit. He mounted his horse. The horse went kha-kha-kha-kha! It arrived at the social gathering. Everyone saw the White man! ${ }^{41}$

Mr. Baulo returned home. He said to his daughter, 'My child, go and fetch Olosi.' She went and called Olosi.

Mr. Baulo said, 'Olosi, the social gathering that took place over there was very big. Hey, we saw a white man. We really enjoyed ourselves.' Olosi replied, 'Really? Is that so?' Mr. Baulo said, 'You, just go to bed.'

The following evening, after he had finished his work for the day, Mr. Baulo called his daughter. He said, 'Go and call Olosi.' That girl came to Olosi's house and quietly peered into the window. She saw Olosi lifting his star. A lot of money appeared in front of him. He was red like a White man!

She called out, 'Hey, Olosi! You have been summoned to the chief's place!' Olosi quickly started closing his star, but the girl said, 'Do not close it! Do your magic for me.' Olosi refused. She pleaded and pleaded. He relented and opened his star for her.

That child of Mr. Baulo visited Olosi every evening. Mr. Baulo asked, 'What is it you do there with Olosi?' She said, 'Olosi and I like to chat. We just chat. He makes me happy.'

38.A mother's reluctance to see a daughter or son leaving home upon maturity is a common theme in ngano.

39.The character of a thin old man (more often, woman) is a common trigger of action in ngano. Thinness generally is indicative of deprivation and powerlessness, and often elicits reactions of disgust.

40.Vhutamboni, from tamba, to play.

41.Tshamano identified Olosi as one of the service staff at the gathering.
Shortly afterwards the girl said, 'My father, I want a big white wedding. ${ }^{42}$ Her father asked, 'Whom do you want to marry?' She answered, 'Olosi.' Mr. Baulo shouted, 'I will kill him! You will never marry him!'

That child cried and cried and cried! Mr. Baulo said, 'Olosi is not the kind of person one marries! I do not want him! I am chasing him away!'

That White man suddenly arrived there and said, 'Mr. Baulo, wait a moment so that we can first see this person who is called Olosi.' Mr. Baulo replied, 'But Olosi is just the one who stays outside.' The White man said, 'Leave your daughter to do as she wants.'

And so they started to plan the wedding. They waited for Olosi to come. Instead, they found a certain handsome White man on a horse wearing a white suit coming towards them, a White man with money. The horse went kha-kha-kha!

'Is this Olosi?' Mr. Baulo tore his own suit off in frustration and threw it down! He shouted, 'No! This cannot be Olosi!'

He went to Olosi's house but did not find him there. He was confused. 'What is going on here?' Olosi answered, 'Yes, this is really me.'

And so Olosi married his child, he married her. Yes, he lived with her. They had money!

This is where the story dies.

\section{Coming-of-age in a different world}

Olosi's basic predicament is timeless: His is the story of a young man propelled by the libidinal energy of youth to conquer the world. Like Dzwee, he too undergoes a rite of passage in the form of an exciting journey towards adulthood and citizenship. However, in other essential aspects his story could not be more different.

The opening is very familiar in ngano - that which introduces a man with two wives, ${ }^{43}$ and the expectation immediately is that some conflict related to them is about to unfold. ${ }^{44}$ The jealousy that ensues is typical of the relationship between co-wives, and the guilty party almost always receives short thrift. ${ }^{45}$ However, this theme unconventionally is not developed here, and the conflict arising from jealousy merely serves as the motivation for Olosi to leave home. As in Dzwee's case, here too all is not well.

As mentioned, coming-of-age narratives often portray conflict related to the potential of a young person, especially in relation to spiritual power. Individuals with such capacity often become entangled in webs of conflict, and they consequently invoke a range of strategies to support their status (Kruger 1999). In ngano, for example, a boy frequently

42.Mutshato, a wedding in the Western style, as opposed to mbingano, a traditiona wedding.

43.The reason for this is that ngano essentially address relationships within the extended family.

44.In extreme cases the conflict between co-wives takes the form of the murder of a child. In this regard see Kruger (2013:188-190).

45.Ngano consequently are described as milayo nyana, 'small laws' that regulate social conduct. Cases of jealousy often are referred to diviners who find transgressors guilty in terms of ancestral moral norms. In the most extreme instances, such as murder rooted in jealousy (see the previous footnote), the guilty wife is executed. 
reveals the capacity to make rain by communicating with the spirit world (Kruger 2013:181-182). He has exceptional command over speech and singing, which manifests social and spiritual power. The boy therefore must prove that he will apply his special ability in accordance with social ideals, in particular to serve communal interests.

Olosi also harbours a spark of divine power, symbolised by his ownership of a magic star. We return to a more extensive interpretation of the star in the next discussion, and only offer a preliminary definition of it here as a symbol of potential individual capacity and self-actualisation. The fact that Olosi not only leaves his community, but also does so with his youthful power unbridled and unmediated, is unusual. However, as we show, this is a crucial attribute of an evolving world view.

Like Dzwee, Olosi leaves home to find work, and this act similarly initiates the transitional phase of his journey to citizenship. Dzwee's world is essentially precolonial, although with clear reference to culture contact. ${ }^{46}$ In contrast, Olosi's world fuses the rural and urban, with the dynamic interaction of their states of consciousness. It offers a glimpse of the life of a migrant labourer, of the young man from a rural area who must travel to town, not only for survival, but also to prove his manliness and social competence (Coplan 2001:119). In this process he becomes the narrative trickster hero - the personification of the quest for social change with all its mutually defining polarities (Scheub 2012). ${ }^{47}$ Tshamano, however, denied that Olosi is a migrant labourer, although he explained that the young hero returns home periodically to protect his mother against her envious co-wife. For rural arrivals Stephen Kumalo (Paton 1948) and Kolisile (Venter 1958), the city is a place of continuous hardship, and they ultimately return to their rural homes defeated. ${ }^{48}$ Olosi in contrast has different expectations, and his destiny is inextricably entangled with urbanisation and the political economy of its identity forms.

Central to these identity forms are the names of the heroes. Dzwee is an unusual name, and Tshamano and Mavhetha speculated that it could be of Zimbabwean origin. Venda and Shona populations have close historical and cultural ties dating back several centuries, and they also share ngano performance practice. Whereas Dzwee's name invokes an African identity, the name Olosi (given to the hero by his parents) is derived from Alois, and it consequently establishes a clear link with the colonial encounter and its attendant changes. ${ }^{49}$

\footnotetext{
46.Although the arrival of Indian immigrants to South Africa dates back to the late 19th century, the Venda population historically engaged in trade with Arab traders who travelled down Africa's east coast and into the interior.

47.This is not to suggest that the trickster only emerges during periods of fundamental transition. Sankambe, the Venda trickster, is an enduring narrative character. But whereas Olosi is triumphant at the end of his quest, Sankambe's attempts at undermining the socio-political hierarchy usually have temporary effect only (see Le Roux 1996: 805-902).

48.Kumalo's son Absalom is found guilty of murder, whilst Kolisile is seriously injured in a mine rockfall.

49.The colonial encounter frequently necessitated the adoption of first names of biblical and European origin, in addition to Tshivenda names. However, there
}

Olosi's identity is also expressed in spatial terms. He receives a house from Baulo, but it is far away, at some distance from the social centre: He is 'just one who lives outside.' Put differently, he has arrived in town, his destiny, but he is not yet at home. He remains an outsider, a young man in the liminal phase of his transfiguration. This is manifested by his 'redness' ('He was red like a white man' 'O tswuka e mukhuwa'). ${ }^{50}$ Tshamano identified Olosi as lixwete, a derogative term for an albino person. Olosi's physical appearance therefore expresses attributes of both worlds he inhabits. This means he is a marginal figure - at least initially - a person who does not really belong anywhere. He is accepted by Baulo as a humble employee but not a son-in-law, whilst he is also not welcome at home. The liprefix is frequently used to dehumanise people or identify outsiders (e.g. lidisadzi, an ugly woman; Libuswumane, 'Bushman'). ${ }^{51}$

But a quite different, hidden metaphor of outsidership is also invoked here. Baulo is the Tshivenda form of Paul, a name used generically in the story, but linked instantly by Tshamano to that of Afrikaner President Paul Kruger. ${ }^{52}$ And so it transpires that Baulo and his daughter are white people, and that their meeting with Olosi is a remarkable embryonic representation of the racial and political dynamics of the colonial encounter. ${ }^{53}$ Olosi's outsidership therefore points to forms of residential, economic and political exclusion, a dispensation in the apartheid era that required Olosi for work only, whilst keeping him on the geographical and socio-political periphery.

Unlike that of Dzwee, Olosi's period of initiation is brief - after all, he is the owner of a magic star that enables him to obtain wealth and find purpose in life. Even so, the first phase of his journey is also marked by lack of direction and experience in the ways of the world. And so he meets his first adversary, an ancient and ubiquitous figure in world narrative. The wily old man is the counterpart of the confidence trickster in Paton's Cry, the beloved country (1948), who persuades naive rural resident Stephen Kumalo to hand over the price of a bus ticket when he gets off the train in Johannesburg. The old man's ruse sets the humorous tenor that marks the remainder of Olosi's story. Merely being filthy, he appears mild in relation to the malice of the lion and fish in Dzwee's story. However, his trickery is instrumental since it teaches Olosi a strategy for survival and empowerment he employs when confronting Baulo, his main adversary.

currently is an increasing tendency amongst Tshivenda speakers to give only names of foreign origin to their children.

50.An initial interpretation of this redness as sunburnt white skin (Kruger 2013:203) is incorrect, and was based on incomplete investigation.

51.Compare the respectful $m u$ - prefix (e.g. muthu, person).

52. History is one of Tshamano's school subjects.

53.Given that Matamela Makapile heard ngano at the knee of her grandmother, we can assume that the kernel of Dzwee's story is of precolonial origin, and that Olosi's narrative could date back to the 19th century. Culture contact between Tshivenda speakers and settlers of European origin dates back to the first half of the 19th century, and accelerated with the discovery of diamonds and gold during the latter half of the century. 
Olosi's initial position is desperate - after all, he arrives in town in tatters. But his magic star protects him by providing him with wealth like that of a white man, and, subsequently, by turning him into a person who resembles a white man. Like Alladin's lamp, Olosi's star serves his wildest desires, and it transforms him instantly into a wealthy adult and, subsequently, a person with a light skin. Rossouw (2007:87) remarks that when the spirit is separated from the body and the world, it becomes possible to treat the body purely as a plastic object. Needless to say, this separation is not in keeping with precolonial cosmology, a theme we develop in the final analysis. In any case, magical intervention in human affairs is by no means unusual in ngano, and, as we will reiterate, it typically occurs in situations of perceived hopelessness.

Potent as Olosi's star is, he needs to harness its power to his recently acquired skill for trickery in order to marry. The confrontation between Olosi and Baulo is situated in an ideal climate for deceit, namely a liminal period governed intensively by conflicting sets of rules which unleash unusual forces (Scheub 1999:117). Baulo's resistance to his daughter's unacceptable suitor needs little elaboration in terms of world narrative with its archetypal images of oedipal conflict, here additionally embedded in the template of racial politics. Overcoming a resistant king, marrying his daughter and living happily ever after in wealth are ancient narrative images of self-realisation that accrue new meaning within the socio-political context of Olosi's adventure. In any case, the hurdle of racial exclusion and oppression is cleared, and the rewards of empowerment and social redefinition belong to Olosi. Now, unlike Kolosile, he no longer is a feared outsider, ${ }^{54}$ but an influential and respected member of society.

\section{Olosi and the predicament of modernity}

It has become evident that the stories of Dzwee and Olosi embody a fundamental shift in world view, one that lies at the root of the modern human predicament. Olosi's migration to the city has culminated in wealth and ostensible happiness that triumph over the miseries of colonial history. However, from Dzwee's perspective, Olosi's journey towards self-understanding is incomplete, whilst his new status harbours unforeseen consequences. Olosi has come to rule the kingdom, but the emperor is naked: The rewards of his magic and trickery are illusionary, in fact marking a world of fallacy and pretence whose containment requires new insight and acts of heroism.

Viewed at large, Olosi's predicament is that of a rational materialism driven relentlessly by the teleology of inevitable human progress. The Enlightenment, that watershed in Western consciousness, accordingly defined a rewarding

54.In Venter's (1958) Swart pelgrim (Black pilgrim) rural poverty forces Kolisile to migrate to Johannesburg. Whilst looking for his brother who preceded him, he naively asks for work at a smallholding. The white owner, in fearful response to an earlier attack by black criminals, sets her dog on Kolisile, thus initiating a chain an earlier attack by black criminals, sets her dog on Kolis
reaction of regression until his return to his rural home. existence in terms of economic growth and material prosperity. For French economist Mercier de la Riviere, 'the greatest happiness possible for us consists in the greatest possible abundance of objects suitable for our enjoyment and in the greatest liberty to profit from them' (cited in Bury 1920:173). Likewise, a meaningful life for Adam Smith depended on material abundance and economic development. However, the wretched social conditions that accompanied an industrialising Western Europe tempered the optimism of the Enlightenment. Reaching a notable point of culmination in the revolt of the fin de siècle, Simmel warned in The philosophy of money ([1900] 2004) against 'the unrest, the feverishness, the unceasing nature of modern life, whose unstoppable wheel is provided by money' (cited by Frisby 2004:xx). Indeed, materialism had become geared towards modernity's pursuit of happiness to the point where economic organisation apparently had become selfsufficient, where material wealth had become 'the ultimate mediator between things', even of social relationships and personal fulfilment (Frisby 2004:xxi, xxiii). Olosi's world accordingly is marked by anomie, a condition in which a significant component of the population lacks the means to realise emerging core values, especially those that require the ostentatious display of wealth. Individuals often unravel from older, once all-encompassing webs of spiritual connectedness. Instead, a proliferating secularity frequently is the impetus behind 'hard and unremitting competition for material supremacy and resources' (Campbell 1973:387): Whereas no money can compensate Dzwee for finding the key to the shop, its acquisition becomes an actual objective for Olosi. And so humanity itself is the ultimate crucial mystery:

[T] hat alien presence with whom the forces of egoism must come to terms, through whom the ego is to be crucified and resurrected, and in whose image society is to be reformed. (Campbell 1973:391)

TheEnlightenment's engagement with the prospect of material abundance was motivated by concern for a world marked by poverty and natural disaster (Goheen \& Bartholomew 2008:92). Olosi's objectives similarly are a self-evident response to the ravages of colonialism and the wretchedness of his environment. Folovhodwe and surrounding villages are characterised by extensive unemployment and grinding poverty. The local unemployment rate is estimated at between $45 \%$ and $65 \%$, and most families rely heavily on social welfare and migrant labour remittances (Kruger 2013:31). Many children only receive one simple meal a day from school feeding schemes (often cabbage and porridge), and their families remain tied to the ancient rhythms of the arid, surrounding land with its meagre, intermittent offerings of natural resources. ${ }^{55}$ A local nursery rhyme consequently observes: 'Money makes life possible. They call me money: I am loved by young and old, rich and poor. If I am there,

55.Small herds of hardy cattle graze freely on sparse grassland. The local Nwaned river is exploited by anglers of all ages whilst certain families have access to much river is exploited by anglers of all ages whilst certain families have access to much
sought-after irrigated farmland along its banks. The veld periodically offers modest harvests of wild fruit, the most notable of which is that of the baobab tree (mbuyu). 
life is good. ${ }^{156}$ Local villagers frequently distinguish between extreme emotional distress (vhuleme) and the good life (vhudifho, lit. sweetness) in monetary terms. Those living the good life have money to buy any food whenever they like; vhuleme, in turn, means not having money for food. The rhyme therefore must not be interpreted primarily as an expression of shallow, hedonistic materialism, but of the challenge to survive. Tshamano's mother accordingly is a humble smallscale farmer, and his father receives a disability grant. Young people like him have little means to escape their poverty and their outlook on life often is bleak.

Olosi's story offers redemption from these conditions of deprivation by invoking meaningful images from the political economy of race and post-colonial empowerment. Although these images are rooted in the long local history of mine, domestic and farm labour for white employers, and the consequent material objectification of race relations, Tshamano's role models in fact primarily take shape in local communal life, and in images in the mass media of the materialism of the newly-rich and politically empowered. The wealthy are mockingly defined as 3Cs, a term for the public flaunting of a car, cell phone and cash. The $3 \mathrm{C}$ lifestyle is most evident in the nearby regional capital, Thohoyandou, that burgeoned during the last two decades of the 20th century from a rural village to a massive commercial centre. It is in response to its feverish development that a song noted during the late 1980s, 'I will buy you a TV my wife. They will admire you. Our car is that one with the tinted windows. Doing these things shows my love, man. ${ }^{, 57}$

Viewed from this perspective, Olosi conforms in various ways to several of Fromm's personality orientations (Fromm 2003). In both the receptive and exploitative orientations there is an expectation of the acquisition of material resources from some external source, either as gifts, or by force or cunning (Fromm 2003:45-46). The function of Olosi's star aligns with the wider current notion that wealth is to be wrested from the control of remote forces, that it can be accrued by 'the production of things, mined and manufactured away from home' (Kruger 2013:56, citing Jeff Guy). This outlook is succinctly verbalised by Julius Malema who emerged famously not very far from Tshamano's village in similar modest conditions to become president of the African National Congress Youth League, and, subsequently, Member of Parliament for the Economic Freedom Fighters' Party. It is in the former capacity that he proclaimed, 'We want everything that white people have, this is what we are fighting for ... Money talks. As long as we have no money, we will always be subservient. ${ }^{58}$

The materialistic nature of Olosi's star also links with the precolonial association between stars and the horticultural

56.Tshelede tshiedza vhutshilo. Vha mmbidzaho vha ndi mashele: Ndi funwa nga vhatuku na vhahulwane, vhapfumi na zwishayi. Nda vha hone, vhutshilo vhu a takadza. (Recited by nursery school teacher Alice Tshisevhe [2010], pers. comm.)

57.Ndi do ni rengela TV musadzi wanga. Vha do tama. Goloi ya hone ndi heilani yo phemiwaho wethu. Ndi u mufuna mani. Extract from a song by guitaris Mmbangiseni Madzivhandila, Tshakuma, 1988 (Kruger 1993:387).

58. Extract from a speech made at Bantu Bonke township in the Vaal Triangle by Julius Malema (Louw 2011) cycle. The most important stars were those that appeared during times of planting and harvesting, and Olosi's star arguably retains the older symbolism of fertility, the renewal of life and of physical growth (Stayt 1931:207; Breutz 1969:206-209). Culled from precolonial symbolic stock, the star has acquired a certain autonomy of its own which is:

$[N]$ ot merely a reflex of capitalist reification and rationalization, [but] also in some measure serves to compensate for the dehumanization of experience reification brings with it, and to rectify the otherwise intolerable effects of the new process. (Jameson 1981:63)

That the quest for rectification is replete with contradictions is evident in the absence within the star's semantic field of the fundamental spiritual nature of Dzwee's cosmology. Venus, the morning star, accordingly heralds the day for the Tsonga boys' initiation school: 'She precedes the sun, so she must lead the boys to their new life, from darkness to the light.' (Junod 1927a:75). Junod (1927b:266-275) also documented a fascinating, extensive narrative in which the heroine has a 'brilliant' star on her forehead. This star provides her with beauty. Importantly, however, her beauty seems to be metaphoric, because it is compared to 'that which is in heaven'; in other words, it appears to signify spirituality. Similarly, the central female character in a Xironga narrative 'had a sun on her forehead, and, furthermore, she was the source of life for the whole village' (Baumbach \& Marivate 1973:103). For Olosi, now situated in an urban, industrial setting, various links with the past have become tenuous, if not severed - with the life-giving horticultural cycle as well as spiritual growth and connectedness within a bounded cosmos.

If there is a residue of dreamlike enchantment in Olosi's world, ${ }^{59}$ it appears to take shape in his marketing personality. Whilst the receptive and exploitative orientations help to explain how wealth is obtained, materialist parading is characteristic of the marketing personality for whom a meaningful life requires adapting to fleeting value systems. This kind of person takes the form of a commodity constantly reinvented in accordance with external imperatives (Fromm 1982:146-147). Olosi meets the demands of the marketing impetus by shedding his rural identity, manifested by his liceinfested skin, dressing himself in a white suit, and obtaining a horse: ${ }^{60}$ These objects are symbolic of his new status - of stardom - and they contrast starkly with the symbolism of Dzwee's horse.

Olosi's marketing personality arguably is also evident in his union with Baulo's daughter, who may be yet another object that is magically attracted to and possessed by the young hero. ${ }^{61}$

59. Weber remarks that the fate of our times is characterised by rationalisation and intellectualisation and, above all, by the disenchantment of the world' (cited in Joseph 2003:125).

60.Famous chief Rasimphi Mphaya Tshivhase (c. 1900-1952) was the owner of a horse, and still is remembered for his legendary wealth.

61.This kind of imagery characterises colonialist literature, and in both Under the sheltering sky (Paul Bowles 2009) and Disgrace (John Coetzee 2000) the female protagonist is forcefully dominated in a symbolic inversion of colonial power protagonist is forcefully dominated in a symbolic inversion of colonial power
relations: Lucy Lurie's sexual assault becomes an act of subjugation, the result of 'a history of wrong' (Coetzee 2000:159). 
She facilitates Olosi's access to kingship, since what initially attracts her to him is his wealth ('Do your magic for me'). ${ }^{62}$

Unlike the archetypal heroine who overcomes challenges by means of integrity and courage, Baulo's daughter is manipulative, and applies emotional blackmail by pleading and crying until her desires are met. ${ }^{63}$ So, whilst Baulo's world seems to take on utopian form, it in fact conceals a vulnerable humanity. Baulo's political disempowerment during the early post-colonial era in South Africa has propelled him further into the sphere of economic activity. He has reached the exhilarating peak of materialism, only to find himself plunging vertiginously into a bottomless abyss of meaninglessness (Rossouw 2007:3-4, 90). ${ }^{64}$ His existence offers material security but also the potential for unbearable being. And it is in this sense that Olosi's union with Baulo's daughter takes on broader significance. Whereas depoliticisation has remobilised Baulo economically, it also has driven him behind the walls of his urban mansion. Olosi, in contrast, has accumulated wealth through rapid political empowerment, but simultaneously has severed links with an integrated cosmos. And so, the ultimate historical irony is that the shared humanity of Baulo and Olosi emerges in a joint dilemma, namely to render their brash new world sustainably meaningful, and in so doing, to prevent it from spinning out of control.

\section{Zwivhuya: Qualitative freedom}

The quandary of Homo sapiens is its struggle to transform mere existence into a condition of being, into a sustainably meaningful life. The striving for meaning through materiality at times appears particularly vigorous in societies not yet comprehensively and pervasively disillusioned by the bourgeois dream (Fromm 1982:194). If there is anything to be extracted by them from the painful experiences of established modernity, it is scepticism about reified, materialist values. To Fromm (2005:38), the survival of humanity is dependent on the innovative realisation of a system of integrated values, rather than their mere rhetorical proclamation, or them being swept away by a 'drunken wave of consumption.' This quest is expressed in the toils of the ambiguous trickster hero who exudes the enormous, undifferentiated energy that shapes emerging awareness and social redefinition. But whereas the hero is socially committed and even visionary, the trickster is amoral and self-serving - above all, he lacks foresight (Scheub 1999:116-118; Scheub 2012:12). The essential prerequisite for vision is the kind of knowledge that shatters illusions, that enables insight into the deeper dilemmas of existence (Fromm 1982:47). It is only when humans become aware of who they are and what drives them, that they can

62.Interethnic marriage historically was not allowed within ruling families, nor as a rule in central districts (the situation was different in areas bordering on Xitsonga and Sesotho-speaking populations in the south and west). However, the marriage between Olosi and Baulo's daughter did not offer any dilemma to Tshamano, since it takes place in the 'imagination' (sic)

63.Tshamano explained that the dominant role of Baulo's daughter in her relationship with Olosi is motivated by her need to manipulate her father. Any request by Olosi for permission to marry would have been rejected out of hand by Baulo.

64.'Hierdie [jappies] sou die duiselingwekkende hoogtes van geld bestyg in wat vandag blyk ' $n$ duiselingwekkende sprong in ' $n$ bodemlose leegte was' (Rossouw 2007:90). determine a meaningful course of action (Fromm 2005:30). Joel Netshitenzhe, African National Congress national executive committee member, accordingly criticises what he calls the lack of engagement by South Africa's black middle class in the discourse on the nation's vision and the shaping of positive value systems for society in favour of strategies for survival and climbing the steep social ladder (Sosibo 2012).

To many, the answer to the flood of modernity sweeping across their communities lies in an inchoate, often conflicting conceptualisation of the urgent need to revitalise older forms of social organisation and values. And so narrator Miriam Vhengani of Tshiulungoma introduces a ngano by explaining:

Now, there was a certain man who lived far from other people. This meant that he was able to have a large field. He worked hard to clear the ground. Then he married and lived there with his wife. They had a lot of maize, and different kinds of peanuts. Then their children were born and so they lived as a family while the years passed. (Extract from Kruger 2013:169-171)

Anachronistic as the ngano genre may appear, it expresses a persistent African outlook in which materiality is only one link in a longer, cosmological chain of nature, society and spirituality. Put differently, prosperity is a condition of material security within a web of interconnectedness that marks the 'effective annihilation of the human ego' (Campbell 1968:387-391). The individual may suffer from hunger or suppression, but he is rooted in 'a structuralized whole in which he has an unquestionable place', and where 'he does not suffer from the worst of all pains - complete aloneness and doubt' (Fromm 1946:28-29). And because material possession is divinely sanctioned, there is an ethical obligation of selflessness (Moyo 1999; Murove 2009). A contemporary local children's rhyme notes: 'Greed! You find yours. Boasting like a chick. It grabs insects. This one is mine! I eat, hmm! $!^{65}$ This rhyme offers a critical view of chickens fighting over scraps of food. When one finds something to eat, it refuses to share, and runs away to eat in selfish isolation. The lyrics of a children's musical game similarly note: 'A twig with leaves. It rots for him. ${ }^{66}$ In alignment with a fundamental position also evident in other world views, ${ }^{67}$ this game expresses the notion that material wealth can never ensure ultimate fulfilment (Kruger 2004:62) ${ }^{68}$ Instead, prosperity is defined as zwivhuya, an ancient concept that links to notions of 'vital force, power, prestige, health, good luck' (Van Rooy 1978:7). This is expressed in a ngano by Matamela Makapile that describes the coming-of-age journey of a brother and sister (Kruger 2013:177-180). As the siblings roam the countryside, they have repeated access to material wealth. However, they are accompanied by a bird who sings,

65. Udzima! Wa wana tshau. Wa hina-hina wa nga gukwana. Lo fara ndodo. Itshi nd tshanga! Ndi a la-vho, hammu! (Recited by Gloria Ndwamato, a nursery school tshanga! Ndi a la-vho, hammu! (Recited by Gloria Ndwamat
teacher at Folovhodwe, 27 September 2010, pers. comm.)

66. Tshitari: tshi a mu sinela.

67. See Exodus 16:20-21 in which the Israelites are provided with food by divine intervention. They ignore the command by Moses not to hoard it, and so it rots and becomes infested with worms.

68.This is manifested in the game, variations of which are found worldwide: A twig with leaves continuously switches ownership as children run around the outside of a circle of seated participants. 
'Leave that: Fortune lies ahead. ${ }^{69}$ 'That' refers to concrete possessions, and it gradually becomes evident that fortune (zwivhuya) in fact is the culmination of an ongoing process of rewarding self-realisation within an interconnected cosmos. ${ }^{70}$

The concept of zwivhuya arguably aligns with Fromm's (1946) notion of qualitative freedom. Whilst the Enlightenment initiated an attempt to rid humanity of irrationality and ensure a prosperous existence, there has been insufficient awareness that 'the problem of freedom is not only a quantitative one, but a qualitative one' that requires a 'spontaneous relationship to man and nature' (Fromm 1946:24, 90-91). This relationship is manifested in Fromm's familiar productive orientation that is predicated on the notion of humanity as displaying 'an inherent and deeply rooted desire to be' - to enter into a 'mode of relatedness in all realms of human experience' (Fromm 2003:61-62). Underlying this orientation is the absolute retention of integrity, spontaneity and independence. In practice, it is expressed in 'the proper grasp of the world by reason', by meaningful, productive work, and in the 'experience of union with another person, with all men, and with nature' (Fromm 1963:32). And so Dzwee acts in the world with reason, with the aim of discovering 'what is behind the surface, to recognize the kernel, the essence of reality which surrounds us' (Fromm 1963:170). His rite of passage is a form of expressive behaviour that manifests 'psychological or characterological laws' (Maslow 1954:184). Olosi, in turn, displays intelligence, which is the 'ability to manipulate the world with the help of thought' (Fromm 1963:64). The amalgam of Olosi's orientations (and that of Baulo's daughter) in contrast constitutes coping behaviour, which is:

[A] functional response to an emergency, a problem or a need whose solution or gratification comes from the physical and/or cultural world. Ultimately ... it is an attempt to make up internal deficiencies by external satisfiers. (Maslow 1954:184)

When these external satisfiers take a predominantly materialistic form, humanity may become imprisoned in a reified system of desires and fleeting rewards. It no longer would be a uniquely reflective life form, but one largely reduced to biological existence, defined by what it possesses and the need for power to protect its wealth. In order to keep his magic star for himself, Olosi must flee his community, away from the nexus of productive existence, to a kingdom shaped by power and aggrandisement.

\section{Conclusion}

Viewed injuxtaposition, the stories of Dzwee and Olosi support Booker's (2004) position that the human alienation attendant 69.Litshai izwo: Zwivhuya zwi tshee phanda.

70.Like Dzwee, the young male hero battles and overcomes 'evil', after which the siblings return home to be reconciled with their family.

The notion of non-material wealth is also evident in Shona ngano narratives. As explained in our discussion of Dzwee's name, Venda and Shona populations have strong historical and cultural links. Von Sicard's collection of Shona ngano in the Chikaranga dialect includes a story documented by Frobenius (Von Sicard 1965:192-193). In this story a man hears a voice in a dream (by implication the voice of a deity) that instructs him to turn down offers of wealth such as pearls, voice of a deity) that instructs him to turn down offers of wealth such as pearls, gold, clothes and any other kind of material possession (German, Stoffe; the original Chikaranga narrative is not provided). Instead, he is to accept only an egg. Eggs in Chikaranga ngano are symbolic of personal growth and non-materia implying not its concrete quality but the wealth of human relationships it contains. upon modernity has led to a transformation in narrative practice. Dzwee's story may be regarded as manifesting the 'life-giving force' of premodern existence that welds 'a story together by bringing light, recognition, transformation and wholeness' (Booker 2004:427). In contrast, Olosi's story emerges from a modernist paradigm marked to a significant degree by 'a kind of cosmic and spiritual dead end.' (Booker 2004:425). Dzwee perpetuates a precolonial consciousness: His world is tribal and organic, and he becomes fully integrated into an ancient cosmology that values transcendence in all its forms. His growth is primarily psychological in the sense that he gains effective insight into himself, the world and nature. However, from Olosi's perspective this outlook is insular and even naive, since he does not inherit a secure place in a familiar world. He is the eternal tragic hero 'who is in the process of being born as long as he is alive' (Fromm 1963:275). He necessarily must transcend place, community and culture. And at the end of his triumphant quest lurks the spectre of incomplete self-awareness, knowledge and love. He comes to face another, ultimate challenge, namely the need to transform the whiteness of existence into the whiteness of essence - the unbearable emptiness of reified materiality into the rich connectedness of an integrated world.

Underlying Olosi's quest seems to lurk a deep-seated sense of despondency and desperation since the demands of modernity can only be mediated by an irrational, ancient belief in magical intervention. However, we can only become masters of the world when we become masters of our imagination, and so Olosi's story becomes 'an original and meaningful protopolitical act' (Jameson 1981:149). It constitutes a fusion of ancient oral narrative practice and images from the mass media and history. The story is a fascinating example of postmodern folklore, a genre that involves 'new social roles, new classes, and a new political economy that collectively allow for the reframing of traditional folklore forms in the new space of advanced consumer culture' (Tangherlini 1997:534).

The stories of our two young heroes in this way speak to the predicament of modernity. They leave us with a sense of wonder about Homo narrans, about the compulsion humanity has for the narrative engagement with shared experiences and needs. Matamela Makapile and her grandson Zachary Tshamano are unassuming inheritors of an ancient African narrative practice that conceals almost preternatural insight into the human condition. The issues they raise in relation to self-actualisation in the moral landscape engage the dynamics of contemporary South Africa, and its destiny. They ultimately resonate with history at large, and therefore require our constant critical engagement.

\section{Acknowledgements Competing interests}

The authors declare that they have no financial or personal relationship(s) that may have inappropriately influence them in writing this article. 


\section{Author contributions}

J.K. (North-West University) and A.V. (North-West University) contributed equally to the writing of this article.

\section{References}

Baumbach, E.J.M. \& Marivate, C.T.D, 1973, Xironga folk-tales, University of South Africa, Pretoria.

Becker, E., 1972, The birth and death of meaning, Penguin, Harmondsworth Berglund, A-I., 1976, Zulu thought-patterns and symbolism, C. Hurst \& Co., London. Bettelheim, B., 2010, The uses of enchantment, Vintage Books, New York.

Bowles, P., 2009, Under the sheltering sky, Penguin, London.

Booker, C., 2004, The seven basic plots, Continuum, London.

Breutz, P-L., 1969, 'Sotho-Tswana celestial concepts', in Ethnological and linguistic studies in honour of N.J. van Warmelo, pp. 199-210, Government Printer, Pretoria. (Government Ethnological Publications no. 52).

Bury, J.B., 1920, The idea of progress: an inquiry into its origin and growth, MacMillan, London.

Campbell, J., 1973, The hero with a thousand faces, Princeton University Press \& the Bollingen Foundation, Princeton.

Coetzee, J.M., 2000, Disgrace, Vintage, London.

Coplan, D.B., 2001, In the time of cannibals: The word music of South Africa's Basotho migrants, Witwatersrand University Press, Johannesburg.

Deacon, T.W., 1998, The symbolic species: The co-evolution of language and the brain, W.W. Norton, New York.

Dutton, D., 2009, The art instinct: beauty, pleasure and human evolution,

Bloomsbury, New York.

Frisby, D. (ed.), 2004, 'Preface', in G. Simmel, The philosophy of money, pp. i-Ixxiv, Routledge, London.

Fromm, E., 1946, The fear of freedom, Kegan Paul, Trench, Trubner \& Co., London.

Fromm, E., 1963, The sane society, Routledge \& Kegan Paul, London.

Fromm, E., 1982, To have or to be?, Abacus, London.

Fromm, E., 2003, Man for himself: An inquiry into the psychology of ethics, Routledge, London.

Fromm, E., 2005, On being human, Continuum, London.

Garcia, L.M., 1998, 'The meaning of being human in Ricoeur's philosophy of the will', Budhi 1(4), 65-103.

Goheen, G. \& Bartholomew, C., 2008, Living at the crossroads: An introduction to Christian worldview, SPCK, London.

Granger, L., 2007, Stories gogo told me, Penguin, Johannesburg.

Jameson, F., 1981, The political unconscious: narrative as a socially symbolic act Cornell University Press, Ithaca.

Jonze, S., 2013, Her, motion picture, Warner Bros. Pictures, Burbank.

Joseph, J., 2003, Social theory: Conflict, cohesion and consent, Edinburgh University Press, Edinburgh.

Junod, H.A., 1927a, The life of a South African tribe, vol. 1, MacMillan, London

Junod, H.A., 1927b, The life of a South African tribe, vol. 2, MacMillan, London.

Kruger, J.H., 1993, 'A cultural analysis of Venda guitar songs', PhD thesis, Dept. of Music, Rhodes University.

Kruger, J.H., 1999, 'Of heroes and madmen: Venda zwilombe', South African Journal of Musicology 19(20), 15-31.
Kruger, J.H., (ed.), 2004, Venda lashu: Tshivenda songs, musical games and song stories, School of Music, North-West University, Potchefstroom.

Kruger, J.H., 2008, 'Songs of struggle: power and identity in Venda ngano song stories', Journal of the Musical Arts in Africa 4(1), 1-27. http://dx.doi.org/10.2989/ JMAA.2007.4.1.1.398

Kruger, J.H., (ed.), 2013, The girls in the baobab: Venda stories from the Limpopo Valley, School of Music, North-West University, Potchefstroom.

Kruger, J.H. \& Le Roux, I., (eds.), 2007, The flamboyant rooster and other Tshivenda song stories, School of Music, North-West University, Potchefstroom.

Le Roux, I., 1996, 'Net die woorde het oorgebly: 'n Godsdienswetenskaplike interpretasie van Venda-volksverhale (ngano)', PhD thesis, Dept. Godsdienswetenskap, Universiteit van Suid-Afrika, Pretoria.

Louw, M., 2011, 'Maksimale ontwrigting:Dis wat die jeugliga beplan', Beeld, besigtig 24 October 2011, by http://152.111.1.88/argief/berigte/beeld/2011/10/24/ B1/2/mljuju.html

Masase, P. (transl.), 2011, 'Two ngano narratives', by Z. Tshamano, video recording, Potchefstroom.

Maslow, A.H., 1954, Motivation and personality, Harper \& Brothers, New York.

Moyo, A., 1999, 'Material things in African society: Implications for Christian ethics', in J.N.K.

Mugambi \& N.A. Wasike (eds.), Moral and ethical issues in African Christianity: A challenge for African Christianity, pp. 49-58, Acton Publishers, Nairobi.

Murove, M.F., 2009, 'The incarnation of Max Weber's Protestant ethic and the spirit of capitalism in post-colonial African economic discourse', in M.F. Murove (ed.), African ethics: An anthology of comparative and applied ethics, pp. 221-237, University of KwaZulu-Natal Press, Pietermaritzburg.

Paton, A., 1948, Cry, the beloved country, Penguin, Harmondsworth.

Rossouw, J., 2007, 'n Rooi Z4 en 'n Renaissance-kasteel, Zebra Press, Cape Town.

Rubin, H, 2012, Disconnect, motion picture, LD Entertainment, Los Angeles.

Scheub, H., 1970, 'The technique of the expansible image in Xhosa ntsomi performances', Research in African Literatures 1(2), 119-146.

Scheub, H., 1999, The African storyteller: Stories form African oral traditions, Kendall/ Hunt, Dubuque.

Scheub, H., 2012, Trickster and hero: Two characters in the oral and written traditions of the world, University of Wisconsin Press, Madison.

Schwellnus, P.E., 1937, Ndededzi 1 ya vhana wa Venda, Venda Literature Depot, Tshakuma. Simmel, G. [1900] 2004, The philosophy of money, Routledge, London.

Sosibo, K., 2012, 'Cracks in the rainbow made visible', Mail \& Guardian, 6-12 July, viewed 05 July 2012, from http://mg.co.za/article/2012-07-05-cracks-in-therainbow-made-visible

Stayt, H.A., 1931, The Bavenda, Oxford University Press, London.

Tangherlini, T., 1997, 'Marxist approach', in T.A. Green (ed.), Folklore: An encyclopedia of beliefs, customs, tales music and art, pp. 532-536, ABC-CLIO, Santa Barbara.

Tarnas, R., 1991, The passion of the Western mind: Understanding the ideas that have shaped our world view, Pimlico, London.

Turner, V., 1967, The forest of symbols: aspects of Ndembu ritual, Cornell University Press, Ithaca.

Van Gennep, A., 1960, The rites of passage, Routledge \& Kegan Paul, London.

Van Rooy, J.A., 1978, The traditional world view of black people in southern Africa, Institute for the promotion of Calvinism, Potchefstroom University for Christian Higher Education.

Venter, F.A., 1958, Swart pelgrim, Tafelberg, Cape Town.

Von Sicard, H., 1965, Ngano dze Cikaranga: Karangamärchen, Studia Ethnographica Upsaliensia, Uppsala. 


\section{Appendix 1: Tshivenda transcriptions ${ }^{71}$ \\ Lwendo Iwa Dzwee}

\section{Salungano, salungano!}

Hovha hu muniwe muthannga a tshi pfi Dzwee. A dinalea hayani. A semana na vhabebi. A nala a ri, 'Ndi a tuwa!'

A tshimbila a ya dakani lihulu line a sa divhe uri ndi la gai. A swika a wana ndau. A lingedza u shavha. Ya ri, 'U songo shavha! Idani u ntomole mupfa, ndo thavhiwa.' A ya, a i vangula. Ya ri, 'U songo tshimbila u tshi vhudza muthu na muthihi zwauri wo vangula nne, nahone wo amba na nne.'

A tshimbila a swika a wana khovhe i nnda ha madi. Ya ri, 'Hee, iwe, Dzwee! Ida u ndzhie u mposele madini!' Dzwee a lingedza uri u a shavha. Ya ri, 'U songo shavha, mara fhedzi u songo vhudza vhathu uri wo amba na nne.' A dzhia khovhe a i posa madini.

A tshimbila a swika a wana bere. Bere ya ri, 'Hei Dzwee! U khou todani afha dakani lihulu-hulu?'

Dzwee a ri, 'Ndi khou sokou tshimbila, a thi divhi hune nda khou ya hone.'

Bere ya ri, ' $U$ do liwa nga zwivhanda ngauri hafha fhethu ndi kule na zwitentsi.'

A namela bere. A gada nayo, a gada nayo! Ya swika ya mu tsitsa zwitentsini. A swika a wana shopo lihulu la magula. A ri, 'Ndi a humbela mushumo.'

Magula vha ri, 'Ri khou fha tshikepe wa namela wa ya oversea wa yo dzhia khii na musadzi.' Vha mufha na zwiliwa a ya oversea. Vha munamedza tshikepe.

Mudi wa hone wo tingiwa nga dzindau. A tshi ri u a dzhena ndau dza ri dzi a mu la. Heila ndau ye a i vangula ya ri, 'Ha liwi, o nthusa hoyu.'

A dzhena mudini. A bva na musadzi. Vha dzhena tshikepeni. Vho no vha vhukati ha Iwanzhe musadzi a dzhia khii a posa Iwanzheni.

Vha tshi vhuya fhala magula vha ri, 'Khii dzi gai?' Musadzi a ri, 'Nne ndo posa madini. Ri a u ruma futhi. Tshimbila u yo pala khii Iwanzheni.'

Vha mushelela na zwiliwa. Dzwee a dzhena kha tshikepe. A dzula maduvha mavhili tshikepeni a Iwanzheni a khou sedza. Heila khovhe ya muvhona ya ri, 'Hee, Dzwee, u khou todo mini afha?' A ri, 'Ndi khou toda khii.'

Khovhe ya langana na dziniwe khovhe madini, ya sedza khii. Ya thunyuluwa na khii. Ya ri, 'Khii khedzi.' Ya mufha khii.

Dzwee a humela murahu. A tshi humela murahu, vha ri, 'Hee, hoyu muthu ri nga si mu badele. O ri shumela zwinzhi. Tshelede ndi nnzhi heyi.' Vha dzhia vha muvalela tshikamarani tsha mulilo. Vha mufhisa, vha mufhisa! A sa fe! A bva a mutshena-tshena-tshena! Havhala magula vha ri, 'Hei!' Inwe boso ya magula ya ri, 'Na nne ndi nyaga u dzhena ndi tswuke sa hoyu.' Ya dzhena ya fa! Magula vhothe vha tuwa. Shopo la vha lawe.

Ha da ndau. Ndau ya ri, 'Hee, Dzwee, u kha di zwi humbula u ri ndi nne ndo u lamulelaho u tshi khou toda u liwa naa?' Dzwee a ri, 'Iwe a u dzuli na vhathu. Tuwa u ye dakani!'

Ha da khovhe. Khovhe ya ri, 'Hee, Dzwee, u kha di zwi humbula uri ndi nne we nda u thusa nga u todela khii naa?' Dzwee a ri, 'Iwe, dzhena madini, iwe a u dzuli na vhathu.'

71.The transcriptions were edited by Tshifhiwa Mashau. Mashau holds a master's degree in education from North-West University (Potchefstroom Campus), and currently resides in Pretoria.
Bere ya da. Ya ri, 'Hee, Dzwee, iwe u kha di zwi humbula uri ndi nne we a u disa afha naa?' Dzwee a ri, 'Iwe, bere, i ya u vha u khou la mahatsi hafhala, a u dzuli na vhathu.'

Ha vha u fa ha salungano.

\section{Olosi o tshila zwavhudi nga murahu}

\section{Salungano, salungano!}

Hovha hu munna a na vhasadzi vhavhili. Munwe musadzi a beba ṅwana a re na magic. A re na naledzi hafha kha phanda. Heila naledzi a i timbula, $u$ a vha muhulwane a wana a na tshelede ine ya vha na mukhuwa.

Houla musadzi a zwi vhona. A dzhia niwana a muposa madini. Houla ṅwana a sa nukale. A dovha futhi. Havhala vho ya khunini a humbula u dzhia houla niwana a muposa madini. A ya a muposa. Vhathu vha mutoda mudi wothe, vha mutoda shango lothe. Muniwe munna a ri, 'Ndo vhona ṅwana ndi tshi khou bva khunini hangei e madini. A songo vhuya a nukala, ende futhi a sa eleli.' Vha ya vha dzhia ṅwana. Vha mudzhia vha vhuya nae mudini.

Houla niwana a zwi vhona uri ndi a fa hafha fhethu. A tibula naledzi yawe a vha muhulwane. A tshi vha muhulwane a ri, 'Mma, ndi a tuwa, ndi yo shuma.'

Vhala vha ri, 'Aa! U a tuwa wa ya u shuma zwino u mutuku so?'

A ri, 'Ndi khou tuwa ndi khou ya u shuma mme-anga. Havha vhathu hu tou nga, vha do mmbulaha.' Ndi u mutendela a thuwa a yo shuma.

A tangana na tshiniwe tshinna tsho ambara mukumba $u$ re na dzinnda. Tsha ri, 'Hee iwe! U khou ya u shuma wo ambara sutu naa? U nga si do vhuya wa wana mushumo na luthihi.'

Houla muthannga a ri, 'Mphe hezwo zwe wa ambara.' A mufha mukumba. Hetshila tshinna tsha tuwa tsho ambara sutu.

A tshi swika mudini muniwe vha ri, 'Rine a ri todi muthu wa dzinnda.' A pfuka a ya kha muniwe mudi vha ri, 'Rine a ri todi muthu wa dzinnda.' Ha pfi, 'Nne ri tou ya ha khosi Vho-Baulo.'

Vho-Baulo vha ri, 'Idai, ndi u thole.' Vha mufhalela kudu kwawe kule na nndu yavho. Vha tshi tou ya vha tshi muvhidza nga mushumo.

Hoyu muthannga o vha a tshi pfi Olosi. Houla muthannga: Ha ri vhusiku ha u thoma a edela. Ha vhuvhili a tibula naledzi heila a wana e mukhuwa a na tshelede.

Nga duvha li tevhelaho havhala munna vha ri, 'Olosi u sale na nndu-hii. Ndi khou thoma nda ya vhutamboni. Hu na mukhuwa ane a khou ya u vhoniwa.'

Vha tuwa, Olosi a sala. A tibula naledzi yawe. Ha da bere tsini. A ambara sutu tshena. A namela bere yawe. A ri, kha-kha-kha-kha! A swika vhutamboni. Vha muvhona.

Havhala Vho-Baulo vha vha vha a vhuya. Vha ri, Nंwananga, iyani u vhidza Olosi.' Vho-Baulo vho vha vhe na nwana muthihi fhedzi wa musidzana. Vha tshi vhidza Olosi.

Vha ri, 'Olosi, hovha hu zwihulu zwe zwavha zwi tshi khou itiwa hangei. Hei, hovha hu na mukhuwa o da namusi. Namusi ro diphina. Mukhuwa ro muvhona.' Olosi a ri, 'Ndi zwavhudi..' Ha pfi, 'Iwe, tuwa u yo edela.'

Nga li tevhelaho nga madekwana o no fhedza u shuma mishumo yawe yothe vha vhidza niwana wavho wa musidzana. Vha ri, 'Iyani, ni yo mmbidzela Olosi.' Houla musidzana a swika a tou dodela. A wana Olosi o tibula naledzi. Phanda hawe huna dzitshelede, o tswuka e mukhuwa. 
A tshi vhidzelela a ri, 'Hee, Olosi! Hu pfi idani!' A tshi tiba, a ri, 'U songo tiba!' A ri, 'Nnyitele ndi vhone.' Olosi a hana. A muluvhelela, a muluvhelela. A vhuya, a tenda. A mu itela. Vhusiku vhuniwe na vhuniwe houla ṅwana wa Vho-Baulo a tshi dzula e henengei.

Vho-Baulo vha ri, 'U ya u todani hangei ha Olosi?' A ri, 'Olosi u vha a khou nndzuwela, ri vha ri tshi khou tou dzuwa. U vha a tshi khou ntakadza.' Hu si kale-kale houla musidzana a ri, 'Khotsi anga, a vha nnyitele mutshato muhulu.'

Vha ri, 'U nyaga u malana na nnyi?' A ri, 'Na Olosi.' Vha ri, 'Ndi do mu vhulaya! Zwino, Olosi a si muthu wa u malea!'

Houla ṅwana a lila, a lila, a lila! Vha ri, 'Olosi a si muthu wa u malea. Nahone Olosi ndi khou mu thatha a tshi tsha mutoda.'
Haala mukhuwa a ri, 'Vho-Baulo a vha thome vha ime muthu hoyu wa u pfi Olosi ri thome ri muvhone.' Vha ri, 'Ndi Olosi wa nndara.' Ha pfi, 'Kha vha mulitshe a ite zwine a khou funa hoyu niwana.'

Wa itiwa mutshato. Ha sala zwauri Olosi a de. Vha wana hu khou bvelela muniwe mukhuwa nga bere o ambara sutu tshena o naka, mukhuwa a re na tshelede. Bere ya ri, kha-kha-kha!

'Ndi ene Olosi hoyu naa?' Vho-Baulo vha vula sutu vha lata fhasi! Vha ri, 'A si Olosi hoyu!' Vha tshi yo sedza nduni vha wana uri Olosi haho. Vha tshi ri, 'Mini ndi mini?' Olosi a ri, 'Ndi nne.'

A tshata na niwana wavho, a mumala, a dzula nae. Avha na tshelede! Havha u fa ha lungano. 